\title{
IMPROVING TEACHER'S ABILITY THROUGH TRAINING IN LEARNING STRATEGIES BASED ON COOPERATIVE STAD TECHNIQUES
}

\author{
Triasianingrum Afrikani, Etin Solihatin, Diana Nomida Musnir \\ Universitas Negeri Jakarta, Jakarta, Indonesia \\ E-mail: triasianingrumafrikani_tp02s3@mahasiswa.unj.ac.id
}

\begin{abstract}
This research aims to improve the ability of teachers through cooperative learning strategies based on STAD techniques in grades VII, VIII, and IX at Junior High School 8 Bogor. This study using the method of action research. The model chosen in this action research is Lewin's cycle model in Mills which has the view that action research is depicted as a spiral cycle and includes stages: (a) planning (plan), (b) action (act), (c) observation, and (d) reflection and revision of action plans in the cycle if they are still needed for improvement. The results showed that 1) The application of the STAD cooperative learning strategies through training proved to contribute to the second cycle and the third cycle on improving the ability of teachers to design lesson plans; 2) Implementation of learning with cooperative learning strategies STAD techniques, the exploration of teachers provides information with learning media to be analyzed by students, the elaboration of the teacher guides the discussion where each group has a peer tutor and motivates each group to do cooperative skills; 3) The implementation of STAD techniques of cooperative learning techniques through training in the implementation of preliminary learning activities contribute to the second cycle in the third cycle on improving the ability of teachers to carry out preliminary learning activities. The STAD strategy can increase the ability of teachers.
\end{abstract}

Keywords: Teacher's Ability; Cooperatives; Learning Strategies; STAD

\section{INTRODUCTION}

Efforts to educate the nation's life are built on the principles of democracy, decentralization, justice, and upholding human rights. These principles have a fundamental impact on the content, process, and management of education, resulting in new demands in all aspects of life, including demands for the need to reform the education system. Many things must be considered in the renewal of the education system such as facilities and infrastructure, funding of students and educators, professional management, and improving the ability of educators.

Improving the quality of education is improving the quality of learning. The government has incurred huge costs, a lot of energy, a long time, such as giving upgrades to teachers, building teacher organizations for each subject so that they can conduct subject matter teachers or MGMP discussions, procure books and learning tools, curriculum development, repair facilities, and education infrastructure.

The quality of education can be seen from how much the learning atmosphere supports the creation of learning activities that are interesting, challenging, fun, and meaningful for the formation of educational professionalism. In terms of media learning, quality can be seen from how effective learning media is used by teachers to increase student learning intensity. From the perspective of learning facilities, quality can be seen from how contributive physical facilities are to creating safe and comfortable learning situations. From the material aspect, quality can be seen from its compatibility with the goals and competencies that must be mastered by students. Therefore, improving the quality of learning can be achieved if there is an intensity of systemic and synergic linkages between teachers, students, curriculum, teaching materials, media, facilities, and learning systems in generating processes and achieving optimal competencies in accordance with curriculum demands.

Planning the learning process, in general, can be made with the school or made by each teacher. The teacher's ability to prepare the learning process is a responsibility in developing subject matter and has an important role in teaching students. In teaching, the teacher is not the only source, but a teacher should be able to explore and develop the potential of every child. One way that can be taken is to manage learning that can provide opportunities for children to be involved and express all their potential. 
The results of interviews with class VII teachers, class VIII and class IX, the problem faced by Bogor Negeri 8 Middle School is that before the implementation of learning $70 \%$ of teachers had made a Learning Implementation Plan (RPP), but were not designed by themselves because it was arranged together -sama at the time of MGMP, of which $30 \%$ never made lesson plans, there were $100 \%$ teachers who used the lecture method, and there were $70 \%$ of teachers occasionally making learning media, of which $30 \%$ of teachers never made learning media, there were $100 \%$ teachers never making LKS, so using LKS that has been owned by each student, and $100 \%$ of teachers never form cooperative groups (heterogeneous) which is usually done is that students are asked to form groups individually, In the end the teacher tends to teach monotonically or classically or centered on teacher, students are more silent listening to explanations, taking notes of things that are considered important and doing the assignments given by the teacher, and the opportunity for students to communicate and interact with one another does not occur even to develop the development of children's socialization, so that social awareness is low. Such attitudes and conditions can cause many students to feel alienated, unstable emotions, not confident, eventually will affect the environment and social inequality. The reality in school shows that there are $100 \%$ of teachers not providing guidance and motivation when the group is in the discussion, so that individual competition is getting stronger, and the results of the test/quiz are many students who repeat or remedial. Such conditions will have an impact on not achieving learning objectives.

In relation to the above, creative teachers are always required to focus on efforts to create learning conditions that allow students to learn, so that they do not only transfer the knowledge they have but rather facilitate student learning activities. Therefore a teacher should have the ability to determine learning strategies that are in accordance with the characteristics of junior high school (SMP) students and teaching materials and apply them to the steps of learning activities. The learning strategy that fits the above problem is the cooperative learning strategy of the STAD technique (Student Team Achievement Division). Discuss teaching materials (LKS) for high-ability students to become peer tutors, after the discussion, is complete, the results of the discussion are presented, there are individual quizzes and teachers prepare a useful scoreboard to determine the progress of students or group abilities and know the group and individual record and the last step the teacher gives rewards for the best groups.

The STAD strategy is one of the learning strategies developed based on social psychology theory and basically uses constructivism. This knowledge should be built by students themselves facilitated by the teacher so that they can involve all existing components optimally so that students can learn actively.

Teachers are a very important factor in efforts to improve the quality of education, especially the quality of the process and learning outcomes. The development of teacher professional abilities has become an individual and user need. The learning process is the process of interaction between students and teachers and learning resources in a learning environment. Reigeluth (1999) said that the success of the learning process can be seen from three aspects, namely (1) the effectiveness of learning, (2) the efficiency of learning, and (3) the attractiveness of learning.

As stated by Miarso (2007), that the success of the learning process includes, (1) the effectiveness of learning is often measured by the achievement of learning objectives, or it can also be interpreted as the accuracy in managing a situation or managing learning; (2) learning efficiency can be interpreted as a match between time, cost, and energy used with the results obtained or doing something right; (3) the attractiveness of learning includes: means that are easily achieved and followed, the contents of lessons that are easy to digest because they have been processed in such a way, the opportunities available that can be obtained at any time needed, messages given at the right time and events, high reliability of performance and satisfying student success, diversity of learning resources that can be used for learning purposes, an atmosphere that is familiar, warm, and stimulating (Reigeluth, 1999). Dick and Carey (1990) also argued that the success of the learning process required planning, developing teaching materials, selecting appropriate teaching materials, selecting learning media, carried out with the step of developing learning. Based on the problems stated above, the general problem is how to improve the ability of teachers to design and implement learning by implementing cooperative strategies of STAD techniques.

\section{LITERATURE REVIEW}

\section{A. Concept of Action Research}

Along with the increasing efforts to improve teacher competence and performance lately, action research is the right choice to improve the learning process. Action research provides opportunities for educators in their learning practices. According to Allen and Calhoun, as quoted by Creswell (1998) that in the scope of schools, action research offers a way to develop staff, to develop teachers as professionals, and to overcome problems that exist in school or class. In fact, the scope of action research provides a means for teachers or educators in schools to improve their practice of taking action and to do so by participating in research.

The opinion of Kember and Mills was quoted by Lundgren (1994) that action research is one of the strategies used by teachers to be able to do self-improvement in the learning process in their respective schools so that the implementation of learning appears better. In line with what was said by Schmuck (1997) that action research is to study the actual school situation to improve the quality of professional self and provide insight into how to achieve learning goals to be achieved. According to Stringer (1999) that community-based action research seeks to change the social and personal dynamics of the research situation so that it is non-competitive and non-exploitative and increases 
everyone's participation, there is a relationship between productive styles of interaction and communication. Similarly, what was said by Kember (2000) that research on suppressing social practices aimed at improving or improving a cycle process, followed by systematic, reflective processes, participatory, and determined by the implementer or practitioner.

Kurt Lewin (1890-1947) was known as the father of action research, people first mentioned the term action research through an article entitled Action Research and Minority Problems in 1946. Kurt Lewin was interested in conducting action research to investigate conditions in organizations that leads to social action.

\section{B. Teacher Ability}

Each profession carried by a person must be accompanied by abilities. Competence describing one's abilities both qualitatively and quantitatively or competency is the ability and authority of the teacher in carrying out his profession. This understanding implies that competence can be used in two contexts, namely: first, as an indicator of ability that shows the observed action. second, as a concept that includes cognitive, affective, and action aspects as well as the implementation stages as a whole.

The progress of the era is getting faster, the teacher is required to be able to adapt thoroughly both to the implementation of education and certain skills that surround it, in addition to personality factors that are increasingly stable and convincing, it is necessary to have competence. According to Kasmili (2015) that teachers as agents of learning must have competence, and competence will be realized in the form of mastery of knowledge and professionals in carrying out their functions as teachers. Competency in question is a set of knowledge, skills, and behaviors that must be owned, internalized, and mastered by the teacher or lecturer in carrying out professional duties.

Besides, the teacher also as an agent of learning is the role of the teacher, among others, as a facilitator, motivator, driver, learning engineer, and inspirational learning for students. Therefore, every teacher is expected to be able to improve knowledge and skills in choosing, grouping, and utilizing various objects found in the environment or outside the school as learning resources for students in accordance with the subjects taught.

\section{Increased Teacher Capabilities}

In addition to teachers as agents of learning, the role of teachers includes facilitators, motivators, drivers, learning engineers, and inspirational learning for students (UU, 2005). Therefore, every teacher is expected to be able to improve knowledge and skills in choosing, grouping, and utilizing various objects found in the environment or outside the school as learning resources for students in accordance with the subjects taught.

Increasing the ability of teachers is crucial to improve the quality of education, for those teachers as agents of learning are required to be able to carry out the learning process in producing quality and bring changes to the ability of students so that they can apply their knowledge in the real world.

Process improvement in conjunction with improving teacher capacity consists of the duties and profession of the teacher, such as the ability to design a plan for implementing learning, managing and implementing learning (Introduction, Core activities such as Exploration, elaboration, confirmation, and Closing). To increase capacity, it is necessary to change the paradigm of teachers as professional teachers who carry out their functions by increasing their abilities in managing innovative learning activities and creating good chances in the learning process. Following what Mayer said in Reigeluth (1999) that students are given an active opportunity to create their knowledge.

Roles and abilities are an integral part of a teacher as a professional. The effort to become a professional teacher to carry out the optimal learning process is: (1) make a plan that is making syllabus and learning implementation plan (RPP), (2) preparing, for example, material preparation (making hand-outs, summaries), methods applied, and learning media that will be used, (3) Trying to find new strategies according to the characteristics of students, (4) self-reflection after each meeting, (5) always hone the basic skills of teaching, (6) try to create a relaxed atmosphere, for example learning while playing, puzzle, (7) expanding and deepening teaching materials according to the level of cognitive development of students, (8) carrying out process assessments that are making student worksheets (LKS) and learning outcomes continuously, (9) able to guide students in developing academic potential through positive activities (scientific work teenagers) non-academic potential (sports) (Syarifuddin, 2011).

The participation of students and teachers in the context of learning becomes very important. Teachers play an active role as facilitators who help facilitate students in learning, namely as resource persons, as managers, and carry out meaningful learning (Yamin, 2011).

\section{Understanding Strategy}

Understanding the strategy according to Smaldino, Lowther, and Russell (2008), the teaching procedure is chosen to help students achieve their goals or internalize content. Examples are presentations, demonstrations, cooperative learning, games, simulations, problem-solving, discussions, exercises, and practices, discoveries, and tutorials. the strategy is basically still conceptual about the decisions that will be taken in the implementation of learning. The method is an effort to implement a plan that has been prepared in real activities so that the objectives that have been compiled are achieved optimally. The method is used to realize a predetermined strategy. Strategy refers to a plan to achieve something, while methods are ways that can be used to implement the strategy. Thus a strategy can be implemented with various methods.

According to Reigeluth (1983) that in general education experts agree that in the learning process applied various learning strategies. The right form of learning strategy in the 
learning process is chosen so that the predetermined learning goals can be achieved by the learner in an effective, efficient, attractive manner.

A strategy applied by the teacher can be combined with various methods that are considered effective to achieve a certain goal. What is the starting point for determining strategy is the formulation of learning objectives clearly so that students can carry out learning activities optimally. therefore, the choice of strategy must remember the criteria: efficiency, effectiveness, and elements of student involvement.

From the description above, it is clear that Strategy refers to a plan to achieve something, while methods are ways that can be used to implement the strategy. Thus a strategy can be implemented with various methods. methods and techniques are part of the strategy. Strategies are prepared by the teacher to achieve learning goals. Whereas various media such as OHP, films, pictures, etc. can be used as part of the chosen techniques.

\section{E. Understanding of Cooperative Cooperative}

Understanding is doing something together to help each other as one team or group. Whereas cooperative learning means variations in learning strategies where students work together in small groups to help each other in understanding a subject or subject matter and each student in a group can achieve a predetermined goal or task. Group members are responsible for the accuracy of group tasks (Slavin, 1995).

Cooperative learning is one of the learning strategies that teachers use to make students help each other in learning assignments or subject matter. Therefore cooperative learning is also called peer teaching or peer tutoring (Lundgren, 1994). Lundgren (1994) argued that cooperative learning strategies are developing abilities from three learning goals, namely the results of learning, tolerance \& acceptance, and the development of social skills. Cooperative learning is a learning strategy where students work together in groups that have heterogeneous abilities.

Arends (1997) also said that cooperative learning has characteristics: (1) student work in groups to achieve learning goals; (2) consists of students who are high, average, and low ability; (3) allowing groups to combine differences in race, culture, and gender of students, and (4) giving reward-oriented groups rather than individuals.

In addition to the characteristics of cooperative learning described above, Johnson and Johnson (1991) also emphasized that there are five principles in cooperative learning, namely: (1) positive interdependence, student group members must say that they need cooperation to achieve group goals; (2) face to face interaction, in collaborating to get good learning outcomes, each group member should sit face to face; (3) the ability to report individually or individual accountability, all group members must have the ability to respond to a problem and develop their ideas for group success; (4) using social skills, if there are several students who lack social skills, they are given guidance on cooperation and good communication to work effectively; (5) the group process of students must be able to evaluate the effectiveness of the group while working in groups, the need to correct deficiencies by helping friends solve problems.

According to Lie (2002), something emphasized in the application of cooperative learning strategies is not just group work or discussion in conventional groups, but in cooperative groups, each member must carry out his responsibilities because in addition to group responsibility there is a system of individual and business account every student will be appreciated. So, cooperative learning strategies can be described as structured group learning systems.

\section{METHODOLOGY}

This study using action research methods defined by Mills (2000) as follows that basically, action research involves the teacher in four stages, namely: (1) identifying the focus of the problem; (2) collecting data; (3) analysis and interpretation of data; and (4) developing an action plan. According to Semiawan (2008), action research must clearly distinguish differences in the characteristics of actions and research, where the definition of action is to improve certain situations and research is to point to systematic investigations that are marked by a set of principles, guidelines, certain procedures and can be evaluated based on validity criteria and beauty. Kamber (2000) also said that research methods that emphasize social practice aim at improvement, a cycle process, followed by systematic, reflective processes, participatory, and determined by the implementer.

Collecting data in this research activity is done through two approaches, namely: (1) observation of the implementation of learning to directly observe authentic facts that occur in the classroom or laboratory, especially including the activities of teachers and students during the learning process as well as student learning outcomes or successes, namely what percentage of students have reached the KKM; and (2) interviews to determine teacher perceptions about cooperative learning strategies in learning, learning activities, and some of the problems faced in carrying out professional duties as teachers. This study involved 10 teachers consisting of: (1) grade VII teachers who guide biology, physics, and English language subjects; (2) grade VIII teachers guiding biology, mathematics, chemistry, and Indonesian languages; (3) grade IX teachers who guide social studies history, social studies geography and English.

This research was carried out in four stages, namely preparation, identification of initial ideas, search and analysis of facts, implementation of actions, as well as data processing and data analysis. The research was conducted in Bogor 8 Public Middle School, namely: class VII. Each level needed for research is Class VII B, class VII E, class VII D. The time of study was carried out for 9 months. 


\section{RESULTS AND DISCUSSION}

\section{A. Results}

1. Results of lesson plan assessment and Observation of Cycle Learning Implementation 1

The results of the training/workshop assessment of Learning Implementation Plans (RPP) and the implementation of cycle 1 learning in Biology, physics, and English class VII, biology, mathematics, Indonesian, and class VIII chemistry, history, English, and geography class IX with an allocation of $2 \times 45$ minutes are displayed in Table I.

TABLE I

RESULTS OF LESSON PLAN ANALYSIS AND IMPLEMENTATION OF LEARNING CYCLE 1

\begin{tabular}{|c|c|c|c|c|c|}
\hline \multirow{3}{*}{$\begin{array}{c}\mathbf{N} \\
\mathbf{0}\end{array}$} & \multirow{3}{*}{ Teacher } & \multicolumn{4}{|c|}{ Observation Aspect } \\
\hline & & \multirow{2}{*}{$\begin{array}{c}\text { Lesson } \\
\text { Plan } \\
\text { Analysis }\end{array}$} & \multicolumn{3}{|c|}{$\begin{array}{l}\text { Implementation of Learning } \\
\text { With Cooperative Strategies }\end{array}$} \\
\hline & & & $\begin{array}{l}\text { Introduc- } \\
\text { tion }\end{array}$ & $\begin{array}{c}\text { Core } \\
\text { Activity }\end{array}$ & Closing \\
\hline 1 & VII Biology & 3,1 & 2,8 & 3,1 & 3,2 \\
\hline 2 & VII Physics & 3,3 & 3,3 & 3,4 & 3,2 \\
\hline 3 & VII English & 3,0 & 2,5 & 3,4 & 3,4 \\
\hline 4 & VIII Biology & 3,4 & 3,3 & 3,2 & 3,4 \\
\hline 5 & $\begin{array}{l}\text { VIII } \\
\text { Chemistry }\end{array}$ & 3,1 & 3,0 & 3,4 & 3,2 \\
\hline 6 & $\begin{array}{l}\text { VIII } \\
\text { Mathematics }\end{array}$ & 3,3 & 3,5 & 3,4 & 3,0 \\
\hline 7 & $\begin{array}{l}\text { VIII } \\
\text { Indonesian }\end{array}$ & 3,3 & 3,3 & 3,4 & 3,0 \\
\hline 8 & IX History & 3,0 & 2,8 & 3,4 & 4,0 \\
\hline 9 & IX English & 3,1 & 3,3 & 3,4 & 3,0 \\
\hline 10 & $\begin{array}{l}\text { IX } \\
\text { Geography }\end{array}$ & 3,1 & 3,3 & 3,4 & 3,0 \\
\hline \multirow{2}{*}{\multicolumn{2}{|c|}{$\begin{array}{l}\text { Total Score } \\
\text { Average }\end{array}$}} & 31,7 & 31,1 & 33,5 & 32,40 \\
\hline & & 3,2 & 3,1 & 3,35 & 3,24 \\
\hline
\end{tabular}

Results The training analysis compiled lesson plans in the first cycle when viewed from the criteria of the level of training ability to prepare lesson plans as much as $20 \%$ of English subject teachers class VII and class IX history subjects still do not meet the standards, and as many as $80 \%$, namely eight teachers the level of training ability to prepare RPP is still below the standard. On average the results of the training assessment compiling the lesson plan level of the teacher's ability in the first cycle are still below the standard, namely 3.2.

The results of the observation of the learning process in cycle 1 showed that the results were still low. In the preliminary activities, there were $40 \%$, namely four subject teachers who did not meet the standards and $60 \%$, namely six subject teachers who were still below the standard of the ability to carry out preliminary activities and the average observation results of preliminary activities were still below the standard is 3.1 .

The results of the observation of the learning process in cycle 1 showed that the results were still low. In activities, as many as $100 \%$, namely ten subject teachers whose ability to carry out core activities are still below the standard. The average results of observations of core activities are also below the standard is 3.35 .
The results of the observation of the implementation of the learning process in cycle 1 showed results still low. In the closing activity, there were $40 \%$ of the four subject teachers who did not meet the standards, and as many as $50 \%$ were five subject teachers who were below the standard and $10 \%$ namely one subject teacher who was above the standard of ability to do closing activities and average The average results of observing sub-standard cover activities are 3.24. The value of the RPP analysis using cooperatives in cycle 1 can be seen in Fig. 1.

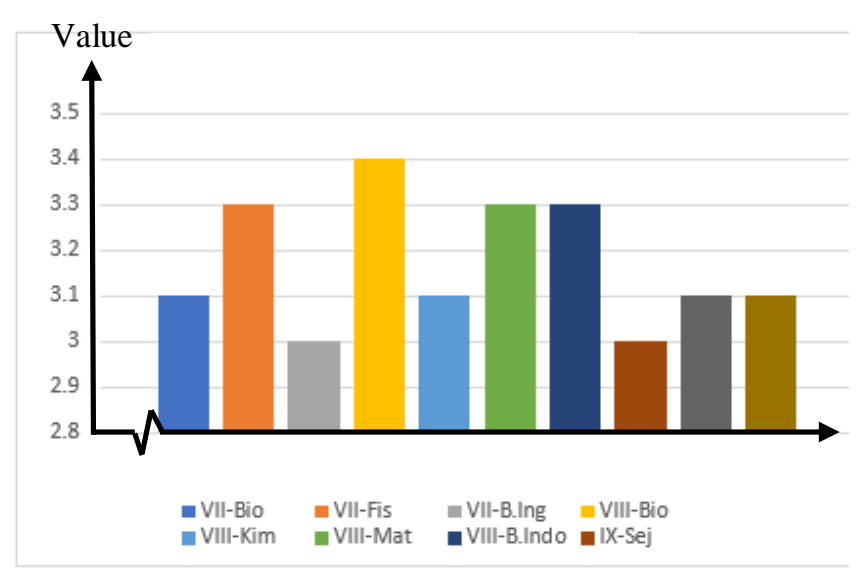

Fig. 1 RPP Analysis Results

Assessment of training in preparing RRP in cycle 1 by using STAD cooperative strategy techniques as many as 10 teachers the level of ability to prepare RPP below standard, the highest level of ability is Biology subject teacher class VIII which is 3.4 but still below standard.

The results of the analysis of the implementation process of learning preliminary activities with cooperative strategies in cycle 1 can be seen in Fig. 2.

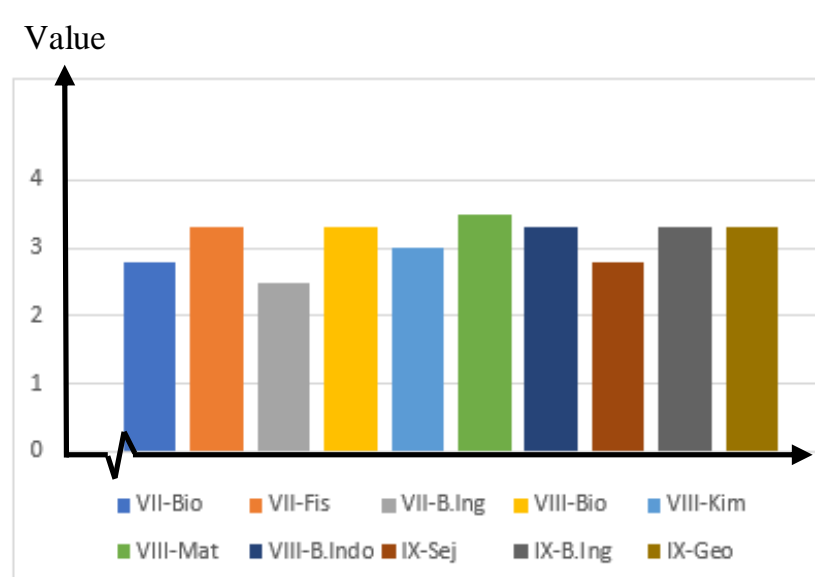

Fig. 2 Analysis results of learning implementation preliminary activities

Implementation of cycle 1 learning, as many as four grade 7 biology and English subject teachers, grade VIII chemistry, grade IX history ability level to do preliminary activities did not meet the standards, because many apperception and motivation activities not done or wrongly 
made or compiled questions for apperception and motivation. Many do not do or inform the learning objectives. Six teachers of grade VII physics subjects, biology, chemistry, and Indonesian language class VIII, English and geography class IX the level of ability to carry out preliminary activities are still below standard. Value of the results of the Analysis of the Implementation of Learning Core activities using cooperative strategies in cycle 1 can be seen in Fig. 3.

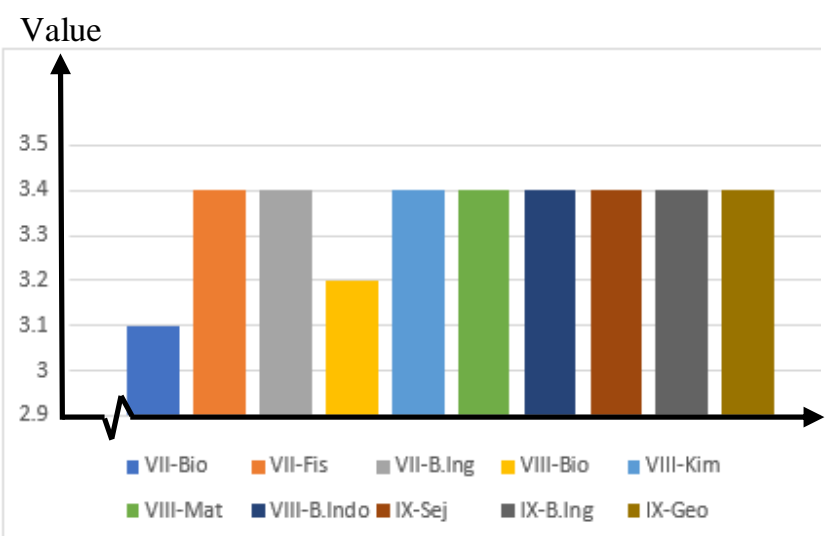

Fig. 3 Results of Analysis of Learning Implementation

Core activities in the implementation of cycle 1 learning, there are 10 teachers whose level of ability to do Core activities is below standard. The core activities consist of exploration, elaboration, and confirmation activities. In exploratory activities, 10 teachers have a level of ability above the standard with criteria 3,6 - 4,0, but in the elaboration activities, 10 teachers do not guide the discussion, because the teacher sits at the teacher's desk does not motivate group discussion, so that cooperative skills do not meet the standards that are, it only reaches 2.2 criteria. Whereas the confirmation activities of 10 teachers have a level of ability above the standard, namely 4.0. The value of the results of the Implementation Analysis Learning activities covers using cooperative strategies in cycle 1 can be seen in Fig. 4.

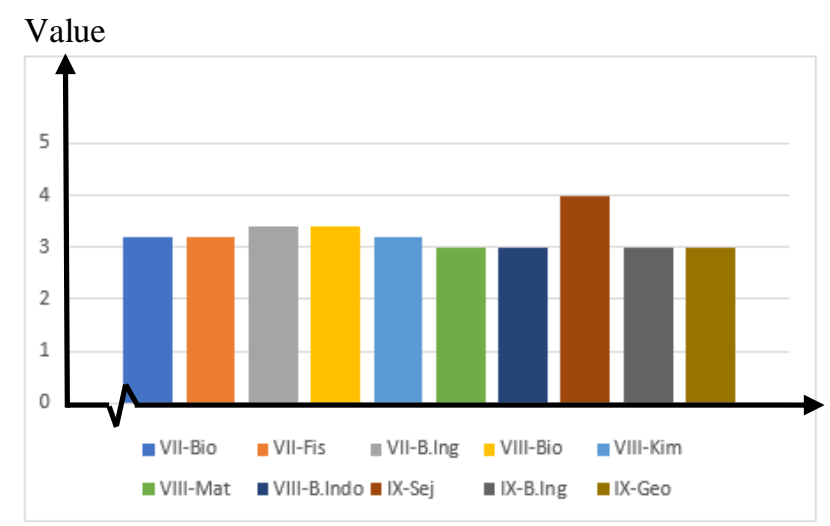

Fig. 4 Results of learning activities in closing activities
In the implementation of the first cycle of learning in the closing activities, there were four mathematics subject teachers, Indonesian language class VIII with the ability level did not meet the standards of conducting closing activities. There are five biologies, physics, English class VII and biology, chemistry teachers in class VIII with a below standard level of ability, because most teachers give questions summarizing doing it poorly, so students don't all answer questions. Almost all teachers do not give learning opportunities to students, and there is one class IX history teacher who can do closing activities above the standard, namely 4.0.

\section{Reflection on cycle 1}

Based on the results of observations relating to the ability of the teacher in designing the lesson plan and implementing the learning process in cycle 1 there are still shortcomings and there need to be improvements to improve the ability of teachers in cycle 2 . The following is a description of the shortcomings of cycle I in the next cycle.

1. In the preparation of the RPP, the average level of ability of subject teachers is still below the standard, because $100 \%$ of teachers have not been able to apply the steps of the cooperative strategy of the STAD technique in the Core activities, namely in the exploration, elaboration and confirmation activities.

2. Apperception questions and motivation are the same, should before giving motivational questions, students are motivated by drawing charts or with transparency

3. It should not forget to convey learning objectives

4. $100 \%$ did not do guidance to all groups during the discussion, the teacher should go around to each group to motivate, guiding that each group performs cooperative skills.

5. The teacher's ability to summarize doing is not good enough, so that not many students are motivated to answer questions summarize, preferably the questions summarize given as much as possible, and try all students to simultaneously answer questions.

6. During group discussions, the sitting position of each group should be face to face or circular.

7. All teachers must allow students to learn, so that individual test results can contribute the best value to the group

8. Almost all teachers are still not right in using time.

\section{B. Discussion}

Based on the exposure of the data previously stated, in this action research several research findings will be discussed in detail. The indicator of the success of the action in this study is an increase in the ability of the teacher to design a Learning Implementation Plan (RPP) and the ability of the teacher in the implementation of the learning process based on the steps of the STAD cooperative learning technique in the lesson plan.

1. The teacher can design learning plans using cooperative learning strategies STADtechniques 
Trainingcompile the steps of learning activities using the STAD cooperative learning strategy in cycle 1, all subject teachers who are collaborators, given training in the ability to plan learning include: (1) formulating indicators; (2) learning objectives; (3) choosing learning material; (4) organizing learning material; (5) choosing learning resources and media; (6) making scenarios or steps in learning activities; (7) choose an assessment technique; (8) make complete assessment instruments. When the teacher prepares a learning plan (RPP), mentoring is carried out, after all the teachers have finished preparing the learning plan, then all RPPs are given an assessment in accordance with the learning plan ability assessment sheet.

Increased ability to prepare lesson plans with the above criteria, for the average ability to develop RPP cycle 1,2 and 3 , namely there is an increase of 3,2 - 3,5 - 3,9 or $80 \%$ $87,5 \%-97,5 \%$ so there is an increase in the ability to arrange learning plans from cycle 1 to cycle 2 there is an increase of $7.5 \%$ and from cycle 1 to cycle 3 there is an increase in the ability of $17.5 \%$ if from cycle 2 to cycle 3 there is an increase of $10 \%$. Seeing the average results of the level of ability to prepare RPP for the first cycle has not met the standards, and in the second cycle the average level of ability is also still below the standard, this is because almost all teachers have never made their lesson plans, usually photocopies from friends teachers at MGMP meetings, training needs to be mainly applied to cooperative strategies in the steps of learning activities especially in core activities, therefore training and training are always needed to arrange lesson plans from cycles 1 through to 3 rd cycle. Average results of increasing teacher skills in preparation of learning planning (RPP) often teachers or $100 \%$ of teachers have reached above the standard in cycle 3 .

2. How is the implementation of learning with cooperative learning strategies STAD techniques

After preparing RPP all teachers set the time according to the learning material that is on the lesson schedule, and prepare learning media, student worksheets made by the teacher, compile formative test questions. The implementation of the learning process with the cooperative learning strategy of the STAD technique, before the teacher, formed a heterogeneous group and those with a higher level of ability later who started to become peer tutors. Exploration activities begin with explaining the material assisted by learning media, students listening and taking notes but after students have a theoretical understanding students are given questions with help with images and then there are questions on transparency, then each group is given LKS, the teacher guides the discussion and motivates cooperative skills that are, stay in the task, cooperate in groups, motivate friends to give opinions/ideas, respect friends' opinions, listen actively and dare to ask questions to group friends or teachers. After group discussion, each group presentation is complete and the teacher guides the discussion and gives the correct concept if a presentation group member gives an incorrect answer.
In the closing activity, the teacher and students summarize the teacher giving questions all students simultaneously answering questions summarizing, then allowed to learn because students will work on formative questions so students can contribute the best value to the group. The teacher prepares a scoreboard to record the test scores and the value of the presentation to determine the best group. Then the teacher gives assignments at home can be structured assignments or unstructured tasks.

3. The teacher can carry out learning in preliminary activities, core activities, and closing activities using cooperative learning strategies STAD technique

a. Ability to carry out preliminary activities

Carry out the learning process in preliminary activities by conducting student conditioning, apperception and motivation, informing learning goals, and dividing heterogeneous groups. When the teacher carries out the learning process the observer makes observations with the observation sheet and the average results of the ability to carry out preliminary activities in cycle 1 are 3.1, which is below the standard, in the second cycle, the average level of ability is 3.45 standard criteria the ability is still below standard. The average level of ability in cycle 3 is 3.9, the criteria are above the standard, meaning there is an increase from cycle 1 to cycle 2 is $8.75 \%$ and from cycle 1 to cycle 3 there is an increase of $20 \%$, from cycle 2 to cycle 3 there is an increase of $11.25 \%$. The average results of the increase in the ability of teachers in the implementation of the learning of the preliminary activities often teachers or $100 \%$ of teachers have reached above the standard in cycle 3 .

b. Ability to carry out core activities

Carry out core activities (exploration, elaboration, and confirmation) including exploration: explaining material with learning media, giving questions to find out student understanding, for elaboration: guiding group discussions, namely motivation and guiding students to do cooperative skills, and to confirmation: manage the class with the presentation of each group.

The average results of cycle 1 exploration activities are 4.0 , the second cycle is 3.84 and the third cycle is 4.0 so for cycles 1,2 , and 3 the level of ability is above the standard. exploration: explaining material with learning media, giving questions to find out students' understanding, the average results of cycle 1 ability level is 3.8 , cycle 2 is 3.8 , and cycle 3 is 4.0 so for cycles 1,2 , and 3 the level of ability is above the standard.

For elaboration: guiding group discussion, namely motivation and guiding students to do cooperative skills, the average results of the level of elaboration in cycle 1 are 2.2. The criteria do not meet the standards, in the second cycle is 3.22 the criteria are below standard and in the cycle, the third is 3.61 criteria above the standard, so the teacher's ability to motivate and guide to do cooperative skills in the third cycle has a good and crystalline improvement on the standard, why does the cycle 1 and 2 not meet the standard and below standard, because the teacher on the first cycle does not guide the discussion so it also does not motivate 
cooperative skills, for the second cycle the teacher has guided the discussion but students have not maximally done cooperative skills.

Confirmation activity: manage the class by guiding the presentation of each group. the average result of the confirmation ability level in cycle 1 is 4.0 criteria above standard, in cycle 2 is 4.0 the criteria are above standard and in cycle 3 is 4.0 the criteria are above standard, so the ability of all teachers to do confirmation activities with criteria are above the standard.

c. Ability to carry out closing activities

Carrying out the learning process in closing activities begins with summarizing with students when the teacher gives a question summarizing all students answering simultaneously so that the teacher knows there is an increase in understanding after the learning process occurs, then the teacher allows students to learn well for donating the best value to the group. Then students work on formative tests and finally, the teacher assigns assignments to each student to do at home, the task can be structured or unstructured.

The average ability to do closing activities in cycle 1 is 3.24 , which is below the standard, In the first and second cycles four teachers do not summarize and do not give learning opportunities to face the test/quiz and in the second cycle, there are still two teachers who still do not properly summarize and do not give learning opportunities to students, so that the average ability to do the closing activities of cycle 1 and cycle 2 is still below the standard.

\section{CONCLUSIONS}

The teacher can design learning plans using cooperative learning strategies STAD techniques Training compile the steps of learning activities using the STAD cooperative learning strategy in cycle 1 , all subject teachers who are collaborators are given training in the ability to plan to learn. How is the implementation of learning with cooperative learning strategies STAD techniques? After preparing RPP all teachers set the time according to the learning material that is on the lesson schedule, and prepare learning media, student worksheets made by the teacher, compile formative test questions. The implementation of the learning process with the cooperative learning strategy of the STAD technique, before the teacher, formed a heterogeneous group and those with a higher level of ability later who started to become peer tutors.

The teacher can carry out learning in preliminary activities, core activities, and closing activities using cooperative learning strategies STAD technique. Carry out the learning process in preliminary activities by conducting student conditioning, apperception and motivation, informing learning goals, and dividing heterogeneous groups. When the teacher carries out the learning process the observer makes observations with the observation sheet and obtained the average results of the ability to carry out preliminary activities in cycle 1 is 3.1 .

\section{REFERENCES}

Arends, I. Richard. (1997). Classroom Instruction and Management. New York: McGraw-Hill Companies. Inc.

Creswell, John, W. (1998). Qualitative Inquiry and Research Design: Choosing Among Five Traditions. London: Sage Publications

Dick, W. and Carey, L. (1990). The Systematic Design of Instruction. Third Edition USA: Harper Collins.

Johnson, D.W. \& Johnson, R. T. (1991). Learning Together and Alone. Allin and Bacon: Massa Chussetts.

Kasmili, C. (2015). Pengelolaan Pembelajaran Kooperatif Tipe Stad ( Student Teams Achievement Division ) Dalam Pembelajaran Produktif. Manajer Pendidikan, 9(2).

Kember, David. (2000). Action Learning and Action Research Improving the Quality of Teaching and Learning. London: Kogan Page Limited.

Lie, Anita. (2002). Cooperative Learning, Mempraktikkan Cooperative Learning di ruang-ruang Kelas. Jakarta: Gramedia Widiasarana Indonesia.

Lundgren, Linda. (1994). Cooperative Learning in the Science Classroom. USA: Glencoe McGraw-Hill.

Miarso, Yusufhadi. (2007). Menyemai Benih Teknologi Pendidikan. Jakarta: Kencana

Reigeluth, Charles M. (1983). Instructional-Design Theories and Models: An Overview of their Current Status. USA: New Jersey: by Lawrence Erlbaum Associate, Inc.

Reigeluth. Charles M. (1999). Instructional-Design Theories and Models. A New Paradigm of Instructional Theory. Volume II. New Jersey: By Lawrence Erlbaum Associate. Inc.

Schmuck, A. Richard. (1997). Practical Action Research for Chage. USA: SkyLinght.

Semiawan, Conny R. (2008). Belajar dan Pembelajaran Prasekolah dan Sekolah Dasar. Jakarta: PT Index.

Slavin, Robert E. (1995). Cooperatif Learning: Theory, Research, and Practice. Second Edition. London: Allyn and Bacon.

Smaldino, Sharon E., Lowther, Deborah L., \& Russel, James D. (2008). Instructional Technology and Media for Learning. Ninth Edition. NJ: Pearson Education Inc

Stringer, T. Ernest. (1999). Action Research, Second Edition. USA: Sage Publications, Inc.

Syarifuddin, A. (2011). Model Pembelajaran Cooperative Learning Tipe Jigsaw Dalam Pembelajaran. Ta'dib, 16(02), 209-226.

Undang-Undang (UU). (2005). Undang-Undang Guru dan Dosen RI Nomor 14 Tahun 2005. Jakarta.

Yamin, Martinis. (2011). Paradigma Baru Pembelajaran. Jakarta: Gaung Perkasa. 